\title{
Multiple Challenges Facing Vietnamese Youth in the Context of the Asean Community Integration Today
}

\author{
Bui Van Tuyen \\ Vietnam Youth Academy, Ho Chi Minh City, Vietnam \\ Email address: \\ buivantuyenpvmn20@gmail.com \\ To cite this article: \\ Bui Van Tuyen. Multiple Challenges Facing Vietnamese Youth in the Context of the Asean Community Integration Today. American Journal \\ of Applied Psychology. Vol. 9, No. 4, 2020, pp. 83-87. doi: 10.11648/j.ajap.20200904.11
}

Received: May 27, 2020; Accepted: June 11, 2020; Published: June 23, 2020

\begin{abstract}
The Association of Southeast Asian Nations (ASEAN) is a political, economic, cultural, and social union of countries in Southeast Asia. This organization was established on August 8, 1967. During the 50 years of establishment and development, ASEAN has achieved many important achievements in all aspects: economy, politics, culture - society, security, and defense. Vietnam joined this largest organization of Southeast Asia in 1995. In the trend of globalization and integration, young people in Southeast Asia in general and Vietnam, in particular, have many opportunities but also face multiple challenges. This paper aims to analyze multiple challenges facing Vietnamese youth in the context of the ASEAN community integration at present. It analyzes problems of youth work in Vietnam. The paper also offers some recommendations for youth work in Vietnam. The author concludes that Vietnamese youth need to have a will and qualifications to promote the advantages and overcome the difficulties. Also, youth work in Vietnam needs to be the work of the entire Party, every party organization, and party member.
\end{abstract}

Keywords: ASEAN Community, Integration, Opportunities, Challenges, Vietnamese Youth

\section{Introduction}

Today, globalization of economy is an indispensable trend taking place in the world, due to the increasingly internationalized production forces, especially since the breakout of scientific and technological revolution. This trend forces countries to have strategies for international economic integration. The international economic integration under the direction of the Party and State is a long, complicated, and arduous process, but it will certainly succeed. The young generation in Vietnam plays an important role in the implementation of the objectives of the international economic integration strategy. Under the leadership of the Party and being educated, trained and fostered in a new environment, Vietnamese youth will surely have the capacity and intellect to fulfill the requirements. Joining the ASEAN community, Vietnamese youth have a lot of opportunities to develop; however, they have to face up with great challenges.

\section{A Brief Literature Review}

\subsection{Definition of Youth}

According to Secretary-General's Report to the General Assembly, "The United Nations, for statistical purposes, defines 'youth', as those persons between the ages of 15 and 24 years, without prejudice to other definitions by Member States" [1]. In 1995, the world youth population - defined by the United Nations as "the age cohort 15-24 - is estimated to be 1.03 billion, or 18 per cent of the total world population" [2]. Other UN entities and regional organizations have somewhat different definitions of youth. For example, UN Habitat use the term "youth" to mean age 15-32. African Youth charter defines youth as those persons between the ages of 15 and 35 years. In this paper, the author use the term "youth" to refer to the persons between the ages of 15 and 35 years.

\subsection{Regional Integration}

In general, regional integration may be political, economic or social. Haas points out that regional integration is a 
process of linking separate economies into larger political economies [3]. Laffan has defined regional integration as a process of creating a larger coherent political system out of separate units, each of which voluntarily cedes some part of its sovereignty to a central authority [4]. States participate in regional integration for their benefits and opportunities. Regional integration encourages intergovernmental cooperation. However, the goverments and the people in each member state have to be ready to face with various challenges.

\subsection{ASEAN Community}

Association of Southeast Asian Nations was established on August 8, 1867, comprising 10 countries including Vietnam with economic, political, and socio-cultural objectives. After 50 years of existence and development, through many ups and downs of the world and the region, ASEAN has achieved many significant achievements and become an organization for regional organizations in all fields. At the 9th ASEAN Summit in Bali, Indonesia in October 2003, the leaders of ASEAN countries decided to establish the ASEAN Community by 2020, comprising three pillars, namely security community, economic community, and sociocultural community. The overall goal of the ASEAN Community is to bring the Association into "a harmonious group of Southeast Asian peoples, intertwined in a community of caring societies" [5]

The Security Community aims to maintain and enhance security, peace, and stability, and promote the ASEAN's ability to ensure its regional security. Nations are collaborating to create a comprehensive regional security that responds to non-traditional challenges, such as transnational crime, terrorism, natural disaster response, and marine security cooperation. ASEAN affirmed its intention not to form a military alliance in the region or a common defense bloc. Member states have the freedom to pursue their foreign policies and set up their defenses.

ASEAN Economic Community aims to make ASEAN a single market and production base. The AEC focuses on creating a stable, prosperous and highly competitive ASEAN economic region where there is a free flow of goods, services, and investment, a freer flow of capital, with equitable economic development, and reduced poverty and socio-economic disparities.

The main measures of ASEAN include the elimination of tariffs and non-tariff barriers; trade facilitation such as harmonizing and standardizing trade and customs, processes, procedures; harmonizing standards, technical regulations, and conformity assessment procedures; completing rules of origin; facilitating services and investment; enhancing the development of ASEAN capital market. However, the AEC does not plan to build a monetary union using the same currency as the European Union (EU).

The primary goal of the ASEAN socio-cultural community is to contribute to realizing an ASEAN Community that is people-centered and socially responsible with to achieve enduring solidarity and unity among the nations and peoples of ASEAN by forging a common identity and building "a caring and sharing society" [6] which is inclusive and harmonious where the well-being, livelihood, and welfare of the peoples are enhanced.

In December 1997, on the occasion of the 30th anniversary of the founding of ASEAN, and after the Association of Southeast Asian Nations included all 10 Southeast Asian countries, the leaders of ASEAN countries approved the important document of ASEAN Vision 2020, with the overall goal is to make the Association "a harmonious group of Southeast Asian peoples, intertwined in a community of caring societies" [7]

Entering the 21 st century, ASEAN has new opportunities for development, but it faces great challenges such as China's rise and power competition in Southeast Asia, the East Sea issue, and a series of security challenges such as religious conflict, ethnicity, drug, and weapons trafficking. These challenges make the regional security environment become precarious. In the economic realm, the risk of recurrent crisis is still potential. Recognizing this, former President of Philippines Gloria Macapagal affirmed that, "In a world of uncertain security and economic flux, we know that the individual nations of Southeast Asia, even one as large as Indonesia or as economically advanced as Singapore, cannot have peace, cannot thrive, cannot hope to prosper, cannot have confidence in the future, unless they work together, stand together, pool their resources, share more and more of their interests, trust one another, and increasingly speak as one in the councils of the world". his statement has been supported by other members in ASEAN.

In October 2003, the leaders of ASEAN countries signed the ASEAN Concord II Declaration, unanimously setting the goal of forming the ASEAN Community by 2020. However, in order to respond to the rapid and complex changes of the regional and international situation, the leaders of ASEAN countries in January 2007 were determined to speed up the intra-regional linkage process based on the legal basis of ASEAN Charter, unanimous for the purpose of forming the ASEAN Community by 2015 (5 years shorter than the original decision).

At the 27th ASEAN Summit in Malaysia on November 22, leaders of nations signed the 2015 Kuala Lumpur Declaration on the Establishment of the ASEAN Community. This is a great achievement in the process of linkage and integration for nearly half- century.

Joining the Association of Southeast Asia Nations (ASEAN) in 1995 is a major milestone in Vietnam's dooropening and integration process to materialize the 7 th National Party Congress's guideline on "diversification and multilateralization of economic relations with every nation", "creation of a favorable environment and conditions for foreigners to invest or do business in the country" and "accession to other international economic organizations and associations when necessary and conditions permit" [8]. Over the past twenty-one years, Vietnam has actively and proactively participated in the ASEAN economic integration and, together with other ASEAN member countries, in laying 
down important foundations for the ASEAN Economic Community (AEC) to be officially founded on December 31, 2015 .

\section{The Great Challenges Facing Vietnamese Youth in Integrating the ASEAN Community Today}

Vietnamese youth are a powerful force with great potential and important contributions to the process of national construction and development. "President Ho Chi Minh and the Vietnamese Communist Party always appreciate the role of the younger generation; pay attention to educating, encouraging and promoting all capabilities of the younger generation to serve the revolutionary cause of the Party and the nation" [9]. In the Testament left to the Party, the people and our army, President Ho Chi Minh advised the Party's responsibility to the Youth as "The Party needs to take care of revolutionary ethics education for them, train them to be the heirs of the socialism building both "ethic" and "professional" characteristics", "Fostering revolutionary generations for the next generation is a very important and very necessary thing" [10].

The Vietnamese Party and people always placed great faith and expectation in the youth, identifying youth as the pillar of the country, the future owner of the country, and one of the factors determining the future and destiny of the nation. Youth work is one of the decisive factors for success or failure in the cause of industrialization, modernization of the country, international integration, and the construction of socialism.

Meeting the requirements of the cause of promoting industrialization, modernization, building, and defending the Fatherland and international integration, the integration of the ASEAN community has created many opportunities for Vietnamese youths to exchange for extensive learning. This is also the process of creating opportunities for the youth to access economic, political, cultural, and social fields in 10 ASEAN countries, expanding their ideas beyond their national borders. This integration process helps the Vietnamese Youth to have an equal position in all aspects with the Youth of the countries in Southeast Asia, and have conditions to "ensure the interests of the country and the nation", and at the same time accelerate the country's reform process. As a member of ASEAN, we have the conditions to improve the learning and living environment and a more professional working environment. Facing that context, most of the Youth are well aware of their responsibilities to the Fatherland and the people, strive to work, study and train in all aspects with the desire to devote themselves to the future of the nation.

The ASEAN common community has created opportunities for all citizens to expand exchanges and seek development opportunities. For young people, this is more important because they are always active, creative, and enthusiastic, so they have more opportunities to interact and learn. Although creating many opportunities, international integration has posed many challenges for Vietnamese Youth as follows:

First, compared to other countries in the region and the world in terms of development level, young people of our country are far behind those of other ASEAN countries, so they have disadvantages in the process of competition in all aspects. The majority of Vietnamese youth still lack knowledge of foreign languages, information technology, and habits of working in the industrial environment.

Second, the country's economy still faces many difficulties and is unable to meet the needs of the youth as well as the people in the fields of study, employment, income and health, entertainment, marriage compared to other countries in ASEAN.

Third, the deep integration leads to increased interdependence among countries. The volatility of the economies of countries may have a strong impact on our country; therefore, the Vietnamese youth are required to be able to forecast, analyze the situation, and have accurate responses to limit the negative impacts outside.

Fourth, the educational attainment and achievement gap has made the employment opportunities for Vietnamese youth in the context of ASEAN integration more precarious even within the country. Youth unemployment and underemployment are increasing day by day.

Fifth, ASEAN integration increasing investment and support from outside Vietnam is a good opportunity, but it also leads to social disturbance, especially for the Youth. Struggling with opportunities to find jobs, many young people have moved away from their homes to urban and industrial areas.

Sixth, under the impact of ASEAN integration, toxic cultural products in many ways, especially through the internet and social media, will directly impact the lifestyle of the youth, causing many difficulties for the protection and promotion of the national cultural identity among young people. The impact of ASEAN integration reflected in both the "thinking and action of young people" [11].

Seventh, the awareness of many young people on international integration is still simple and insufficient. International integration is increasingly deeply and comprehensively affecting all aspects of the youth's life, from communication behaviors, aesthetics, music, sports, entertainment, psychology, career orientation, and job search.

Eighth, joining the ASEAN community, the national border is no longer an obstacle, it is difficult to prevent social evils such as drugs, prostitution, dangerous criminals, gangs. An unhealthy social environment, reproductive health, the rate of HIV / AIDS infection among the youth will continue to be complicated and harm the youth.

Ninth, a part of young people who are weak in politics and fluctuated in political-ideological stance, showing misleading expressions of moral values and lifestyles, "promoting enjoyment, selfish individualism, irresponsible to the community" [12]. The resistance of external forces, the conspiracy to eliminate the achievements of the socialist 
regime, the removal of the Party's leadership, and the division of the great unity bloc of the whole nation pose great challenges for the youth. The objective of the hostile forces is always aimed at the youth, using economic, political, and cultural tactics to affect their opinion to oppose our regime; trying to incite the Youth to participate in activities that destabilize the country's political and security situation.

Thus, ASEAN integration not only brings about opportunities and advantages but also many difficulties and challenges for the youth. Each youth needs to have a will and qualifications to promote the advantages and overcome the difficulties. That is only possible when each youth promotes his spirit of self-study, self-discipline, having qualities and capacities to participate in the cause of industrialization and modernization of the country, and actively participating in the knowledge-based economy, and the international integration process.

\section{Problems of Youth Work in Vietnam in the Context of ASEAN Integration at Present}

Youth mobilization is one of the important tasks of the Party. Right from the beginning, our Party has paid much attention to the youth work. In the process of leading the country's renovation and international integration, the Party affirmed, "Youth affairs are a vital matter of the nation and one of the decisive factors for the success or failure of the revolution" [13]

Over the years, the Youth work has been reformed and achieved many important results. The participation of the Youth in the process of national construction is increasingly clear. It can be said that the contingent of cadres in the public agencies is younger. There are also more and more young faces in the team of businessmen.

However, there are still many limitations in the youth work in the context of ASEAN integration. "There are still policies, movements, or campaigns that are not suitable for youth. Some policies have developed without profound and comprehensive scientific research on young people" [14]. Many activities are formal, not practical to solve the hot issues of the youth. There is a lack of consistent, consistent, and long-term macro policies for youth work. Although the Government has issued many policies to foster and promote the role of the youth, it is still a policy that addresses the situation and is not systematic. The perception of many committees and authorities about the youth work is incomplete, considering the youth work as the task of the Party and the Union, thus not creating the synergy of the whole society in fostering and promoting the role of youth.

Assessing the limitations and inadequacies of youth work, the $7^{\text {th }}$ Plenum of $10^{\text {th }}$ Party Central committee pointed out, "Some party committees have not paid enough attention to youth work. Inspection and evaluation of the implementation of the Party's guidelines and resolutions on youth work are not irregular and timely. Planning, training, retraining, and fostering young cadres have not taken seriously. Party development work among the youth has not done well. The Fatherland Front and many local unions have not cooperated closely and to create a synergy in the youth work" [15]

Youth work is facing new trends and challenges as follows:

Firstly, youth work is not only a national issue but now it is also a deeply regional and international one due to the spread and influence of international integration into all fields of social life. Therefore, it is necessary to have a more specific strategy for the youth in the coming time to guide the integration of the ASEAN community. The reality shows that the Party's orientation and initiatives of integration in the youth work have not well implemented. Vietnamese youths are still passive and confused in the integration process

Secondly, young people have participated in almost all areas of social life such as economy, politics, culture, society and security and defense. In many areas, youth play a key role. This shows that the role and duties of youths have increasingly strengthened, but the youth work has not met the demand. There are many newly established social organizations with the participation of young people but the absence of youths' organizations.

Thirdly, the need for international and regional integration to learn and exchange to improve the qualifications and capacity of the youth is legitimate; however, there is a lack of orientation and management of agencies and organizations. This makes negative external influences easily arise and spread among Vietnamese youth, especially in terms of morality and lifestyle. This is a big challenge for the training of young people.

Fourth, the contingent of cadres in charge of the youth work concurrently hold other positions, and there are very few specialized cadres having expertise in youth work. Lack of trained, and standardized staff specializing in youth work is a big challenge and creates great difficulty for the youth work in the context of integration.

Fifth, the material conditions for youth work are narrowed to other aspects of work, especially in the activities of state agencies.

Sixth, in the context of the market economy and integration, the problem of migrants seeking jobs is common. In many places, there is no member in youth unions, and young people do not have conditions to participate in activities in their organizations. On the other hand, the Youth work has not yet "covered" all subjects, regions, and economic sectors.

\section{Conclusion}

In conclusion, with the above limitations and challenges, Vietnamese youth youth need to have a will and qualifications to promote the advantages and overcome the difficulties. Also, the youth work in Vietnam in the coming time needs to renew in the direction that raising awareness of the party committees and the whole political system for the youth work. The youth work needs to be the work of the entire Party, every party organization, and party member. It is 
necessary to strengthen the Party's leadership on guidelines, personnel work, inspection and setting examples of party members in the youth work. The role of the state for Youth work management needs to promote. It is imperative to accelerate the process of making policies and laws related to youth and youth work. To do that, it is necessary to renew the activities of the youth work, both in terms of organization, education and training of political thought and the gathering methods of Ho Chi Minh Communist Youth Union to educate, and train the youth to become the vanguard in a new era with a bright mind and big ambition. The Youth Union needs to deserve a reliable reserve team of the Party, ready for extensive regional and international integration.

\section{References}

[1] UN Secretary-General's Report to the General Assembly, $\mathrm{A} / 36 / 215,1981$

[2] UN General Assembly Resolution, A/RES/50/81, 1995

[3] Haas, E. 1971. Beyond the Nation-States: Functionalism and International Organization. Stanford, California: Stanford University Press

[4] Laffan, B. 1992. Integration and Co-operation in Europe. London: Routledge

[5] Tong Hoa (2015, November, 22). What is ASEAN Community, Retrieved from https://zingnews.vn/cong-dongasean-la-gi-post603149.html

[6] E-Commerce Newspaper (2014, September, 19), ASEAN towards a caring and sharing society.
[7] Phuong Vu (2017, August, 8). Achievements and challenges of ASEAN after 50 years of establishment, Retrieved from https://vnexpress.net/thanh-tuu-va-thach-thuc-cua-asean-sau50-nam-hinh-thanh-3623810.html

[8] Nguyen Cam Tu (2018, July, 20). New opportunities and challenges for Vietnam. Retrieved from https:/vietnamhoinhap.vn/index.php/article/co-hoi-va-thachthuc-moi-doi-voi-viet-nam---n-5722.

[9] Central Executive Committee of Ho Chi Minh Communist Youth Union (2013). The Scheme: "Enhancing moral education, lifestyle, fostering revolutionary ideals for teenagers in the period of 2013-2020".

[10] The Vietnam Communist Party e- journal (2020, March, 27). "Educating the youth both ethically and professionally according to the Ho Chi Minh Testament".

[11] Pham Minh The (2013). "The impact of international integration on the youth and Youth work today". Journal of Political Theory, Vol. 4.

[12] Vietnamese youth in the context of integration and development. Retrieved from http://media.vovnews.vn

[13] The Communist Party of Vietnam (2016). The Documents of CPV. Complete Volume. Vol. 52. Hanoi: The National Political Publishing House, p. 365.

[14] Pham Thi Nhu Quynh (2015). The Vietnamese Youth in the process of international economic integration, Website of Nghe An Political School, Nghe An Province.

[15] Communist Party of Vietnam (2008). The Document of the 7 th Plenum of the 10th Party Central committee. Hanoi: National Political Publishing House, pp. 38-39. 